\title{
IBM rewards new talent
}

\section{Tokyo} winners of its Japan Science Prize. Unlike Japan's other leading science prizes, the awards go to young (under 45), up-andcoming, Japanese scientists rather than to well-established Western scientists.

Candidates are nominated by university presidents, deans and professors, direcors of national research institutes and IBM visiting scientists in the fields of physics, chemistry, computer science and electronics. The prizes are worth $¥ 3 \mathrm{mil}$ lion $(\$ 20,000)$ each.

This year's winners are:

- Yoshichika Ohnuki of the University of Tsukuba's Institute of Materials Science, for synthesis of the world's one and only heavy fermion material, $\mathrm{CeCu}_{6}$. physics at Keio University for development of a constant-temperature molecular dynamics method for computer simulation of thermodynamic problems.

- Masanori Tachiya at the National Chemical Laboratory for Industry in Tsukuba for development of equations to describe reaction dynamics in inhomogeneous systems (for example, a solid material passing into solution).

- Hiroshi Imai, of the department of computer science and communication engineering at Kyushu University for development of efficient algorithms for computational geometric problems, such as mapping and image analysis.

- Masami Hagiya of Kyoto University's Research Institute for Mathematical Sciences for research on the generaliza-
IBM Japan last week announced the 1989

- Shunichi Nose of the department of

tion of computer programs.

- Hiroyuki Sakaki of the Research Center for Advanced Science and Technology at the University of Tokyo for research on quantum structure and superlattices in semiconductors, particularly those made of gallium arsenide. Sakaki does not quite fit the image of the prize as he is already an established scientist. His research led to the development of the High Electron Mobility Transistors (HEMT) used, for example, in amplification of electric signals in advanced radio telescopes.

David Swinbanks

UNESCO

\section{No signs of a change of heart}

\section{Washington}

Although the US State Department is "currently reviewing actions" taken by UNESCO to reform what were seen here as illiberal policies and an overweight bureaucracy (see Nature 342, 6; 1989), it was officially made clear last week that there is no likelihood that the United States will rejoin the organization soon. The United States, together with the United Kingdom and Singapore, left UNESCO at the end of 1984. The State Department, which released a statement clarifying its position in response to some recent lobbying and newspaper editorializing in favour of rejoining, said only that the government "hadn't seen anything which would lead us to change our policy."

David Lindley MEDICAL RESEARCH COUNCIL

\section{Increase softens blows}

\section{London}

THE UK Medical Research Council (MRC) expresses satisfaction with an increase in support of $£ 82$ million over the next three years in its annual report, released this week. But it says that satisfaction has to be "moderated by the knowledge that the increase... still leaves the Council with a budget which will continue to decline in real terms once the effect of the cash injection wears off".

The one-time injection of funds, announced in February, will allow the council to provide backing for the Human Genome Mapping Project ( $£ 11$ million over three years) and other projects, and to continue its special programmes in AIDS research.

Longer-term planning by the MRC must now wait until January when a decision on the organization of civil research funding is expected from secretary of state John MacGregor. A working party of the Advisory Board to the Research Council
(ABRC) has already examined the Morris report, which proposed that Britain's five research councils should be replaced by a single National Research Council, and submitted its confidential advice to the secretary of state.

The MRC report reiterates its opposition to the Morris proposals, describing them as "damaging to the interests of medical research". Under the Morris proposals, the MRC would remain largely unaltered, as a medical division of the NRC. But what worries the MRC is the possibility that some responsibilities for basic biological research might be transferred to a new biology and environment division of the NRC, meaning that clinical medicine and basic research would be separated. Concern over overlaps in the research councils' responsibility for biological research was a key factor driving the Morris report proposals (see Nature 339, 165; 1989).
Peter Aldhous

\section{Crisis what crisis?}

\section{Washington}

THE US National Commission on AIDS last week harshly criticized US efforts to tackle the AIDS epidemic in its first report to President George Bush. The commission says that a "dangerous" complacency towards the epidemic is developing and calls for major changes in the nation's system of health care.

The commission, an independent body set up in August by Congress to advise Congress and the president on policy issues relevant to the AIDS epidemic, includes members of the Bush administration as well as experts in health care. Its first report was not due until August 1990 , but after interviewing researchers, physicians and public health officials over the past three months, the commission decided that the problems were too urgent to wait until then.

It lays the blame for inadequate health care services on the federal government, which it says has no plan for coping with the epidemic. In the federal government's widely publicized drug control strategy, it fails to acknowledge the link between drug use and HIV (human immunodeficiency virus) infection and in 90 pages of text it mentions AIDS only four times; in the recommendation and discussions on allocation of resources it does not mention AIDS at all.

The commission says that it is estimated that by 1991, AIDS will be among the top ten leading causes of death in the United States and, for people between the ages of 25 and 44, deaths from AIDS will far exceed those from all other causes.

The main problem for many AIDS patients is the difficulty in obtaining health care under Medicaid, the financial reimbursement programme which caters for people with low incomes. Obstacles to obtaining care under the Medicaid system are often insurmountable, says the commission, and any belief that this system is adequate for all those who need it is a "fantasy" according to one witness consulted by the commission. Also contributing to the problems are the "gross lack of training" for doctors to treat people with HIV infection and AIDS, and the "serious disincentives" for doctors to treat poor people.

At the top of its list of requests is that there should be a frank recognition that a crisis exists, accompanied by a clear definition of the responsibilites within government for tackling the problem. The commission also calls for a network of regional centres to care for patients as well as for special units to treat drug addicts who are HIV-infected.

Christine McGourty

NATURE · VOL 342 · 14 DECEMBER 1989 